\title{
Effectivity of topical mangosteen pericarp extract cream on wound healing in Swiss albino mice
}

\author{
Hilda Brigitta Sombolayuk, ${ }^{1}$ Khairuddin Djawad, ${ }^{1}$ Siswanto Wahab, ${ }^{1}$ Upik A. Miskad, ${ }^{2}$ Gemini Alam, ${ }^{3}$ \\ Ilhamjaya Pattelongi ${ }^{4}$
}

${ }^{1}$ Department of Dermatology and Venereology, Faculty of Medicine, Hasanuddin University, Makassar; ${ }^{2}$ Department of Anatomical Pathology, Faculty of Medicine, Hasanuddin University, Makassar; ${ }^{3}$ Department of Pharmacognosy, Faculty of Pharmacy, Hasanuddin University, Makassar; ${ }^{4}$ Department of Physiology, Faculty of Medicine, Hasanuddin University, Makassar, Indonesia

\begin{abstract}
Wound healing is a complex physiological process consisting of four phases: coagulation, inflammation, proliferation and migration, and remodeling, each with distinct characteristics. Studies have suggested that mangosteen pericarp extract (MPE) may accelerate wound healing. However, the mechanism has not been fully understood. This study aims to evaluate the effect of MPE cream in various concentrations in acute wound healing of albino mice, both histologically and macroscopically.

Thirty-two healthy female Swiss albino mice, aged 6-9 weeks, weight 20-30 g, were included in this study. The samples were randomly divided into eight groups each consisting of 4 mice. The
\end{abstract}

Correspondence: Hilda Brigitta Sombolayuk, Department of Dermatology and Venereology, Faculty of Medicine, Hasanuddin University, Jl. Perintis Kemerdekaan KM. 11 Tamalanrea, Makassar, South Sulawesi, Indonesia.

Tel. +62.81245604085 .

E-mail: hilda_brigitta@yahoo.com

Acknowledgements: the authors would like to thank everyone who has participated and assisted in this experiment.

Key words: Anti-inflammation; Granulation tissue formation; Mangosteen pericarp extract cream; Reepithelialization; Wound healing.

Contributions: the authors contributed equally.

Conflict of interest: the authors declare no potential conflict of interest.

Funding: none.

Received for publication: 5 March 2019.

Revision received: 26 July 2019

Accepted for publication: 27 July 2019.

${ }^{\circ}$ Copyright: the Author(s), 2019

Licensee PAGEPress, Italy

Journal of Biological Research 2019; 92:8150

doi:10.4081/jbr.2019.8150

This article is distributed under the terms of the Creative Commons Attribution Noncommercial License (by-nc 4.0) which permits any noncommercial use, distribution, and reproduction in any medium, provided the original author(s) and source are credited. first four groups were treated with MPE cream 5\%, 10\%, and $20 \%$, and no medication (control group), respectively, and were sacrificed after three days. The other four groups received the same application and were sacrificed after 8 days. Wound bed diameter was measured and biopsy from the skin lesion was performed for histopathologic examination. Mann-Whitney test was used to analyze the diameter of the wound bed and histopathological findings of granulation tissue formation, reepithelialization, and inflammation, with $\mathrm{P}<0.05$ considered as significant.

MPE cream significantly improved wound healing by increasing granulation tissue formation, and reepithelialization. In addition, MPE cream application was also shown to decrease the number of inflammatory cells, particularly in 5\% and $10 \%$ concentrations, both in the 3-day and 8-day groups.

MPE cream application can accelerate wound healing and thus can be used in acute wound treatment.

\section{Introduction}

Cutaneous wound healing is a complex and essential physiological process that depends on the interaction of cytokines, growth factors, chemokines and chemical mediators from cells to perform regulatory events. ${ }^{1-3}$ Tissue regeneration and repair process begin immediately after an acute injury following any stimuli that interferes with the physical continuity of functional tissue. In general, there are four recognized phases that characterized the cutaneous repair process: coagulation, inflammatory phase, proliferative and migratory phase and remodeling phase. The coagulation and inflammatory phases are sometimes grouped together. ${ }^{1,2,4}$ These phases are distinct in function and histological characteristics. In acute wound, there is an orderly progression from injury to coagulation, inflammation, cell migration, and tissue remodelling. ${ }^{2,5}$

As the inflammation resolves, the involved cells enter into apoptosis and initiate the proliferative phase, which consists of four fundamental stages: reepithelialization, angiogenesis, granulation tissue formation, and collagen deposition. ${ }^{2}$ During reepithelialization, the keratinocytes migrate from wound and multiple regulators such as growth factors and cytokines, integrins, keratins, matrix metalloproteinases (MMPs), chemokines, and extracellular macromolecules stimulate epithelial attachments. Remodeling is marked by the extracellular matrix (ECM) reorganization, cells apoptosis and angiogenesis regression, and type III collagen replacement by type I collagen. ${ }^{2}$ 
A variety of active agents has been used to accelerate wound healing process such as antimicrobials and antibiotics, epithelial growth factor, fibroblast growth factor, vitamins and minerals, and wound dressing material from naturally extracts. ${ }^{6}$ Mangosteen (Garcinia mangostana Linn.) is a tropical fruit mostly found in Southeast Asia, including Indonesia. It is also known as the queen of fruits and its pericarp has been used in traditional medicine in Southeast Asia for centuries to treat infection, wound, infection, and diarrhea. Xanthones are among the mangosteen metabolites that have been successfully isolated from the pericarp of mangosteen and they have been attributed to the medicinal properties of the fruit. At least 68 distinct xanthones have been identified in different parts of the plant with 50 being present in a higher concentration in the pericarp than in the edible portion of the fruit. The most abundant xanthones in the pericarp of mangosteen are $\alpha$ - and $\gamma$ - mangostin. ${ }^{7,8}$ Several studies have revealed that mangosteen pericarp extract (MPE) exhibit antimicrobial, anti-proliferative, antioxidant, anti-inflammatory, and analgesic properties. ${ }^{9,10}$

A recent study has determined the effect of different concentrations of ethanol extract gel formation of mangosteen pericarp on wound healing in burns. ${ }^{11}$ However, there is lack of studies evaluating the effectivity of topical application of MPE cream for wound healing. The present study aims to evaluate the effect of ethanolbased MPE cream in various concentrations in acute wound healing in albino mice, both histologically and macroscopically.

\section{Materials and Methods}

This post-test only, true experimental study with control group was conducted in Animal Laboratory and Pathological Anatomy Laboratory of Hasanuddin University, Makassar, Indonesia, from November to December 2018 with the approval from Hasanuddin University Ethics Committee. The samples were 32 Swiss albino mice, with inclusion criteria consisting healthy females aged 6-9 weeks, weight 20-30 g. The mice were excluded if they had died during the study.
MPE cream at $5 \%, 10 \%$, and $20 \%$ concentrations was made in the laboratory of Phytochemical Pharmacognosy, Faculty of Pharmacy, Hasanuddin University. A 5-mm wound was made in each experimental mouse by a 5-mm punch biopsy and treated with twice daily application of MPE cream. The samples were randomly divided into 4 groups each consisting of 4 mice. Each sample in the first four groups was treated with MPE cream 5\% (A), 10\% (B), 20\% (C), and no treatment (E), respectively, before being sacrificed after 3 days. The other four groups received the same treatment, labelled A1, B1, C1, and E1, and were sacrificed after 8 days.

After three days, sample group A, B, C, and E were sacrificed. Wound bed diameter was measured and recorded. Sample of skin tissue was taken from each mouse by excisional biopsy from wound bed and normal adjacent skin for histopathological examination. These specimens were fixed with buffered formalin, embedded in paraffin wax, cut into 3-4 $\mu \mathrm{m}$ sections and stained with hematoxylin-eosin. The sections were then examined with light microscope (Dual Head Olympus CX41). The same procedure was done with group A1, B1, C1 and E1 after 8 days.

Wound healing was assessed by analyzing granulation tissue formation (GTF), inflammatory cells count (ICC), reepithelialization (RE), and diameter of wound bed in millimeters (D). Granulation tissue formation was graded by score $1-3 \quad(1=0-25 \%$ GTF with inflammatory cell domination, $2=50-75 \%$ GTF with wide neovascularization and less fibroblast, and $3 \geq 75 \%$ GTF with domination of collagen and fibroblast). Reepithelialization was graded by score 1-3 ( $1=$ no $\mathrm{RE}, 2=\mathrm{RE}<50 \%$, and $3=\mathrm{RE}>50 \%$ ). Inflammatory cells count was graded by score 1-3 ( $1=$ mild macrophage and neutrophil, $2=$ moderate macrophage and neutrophil, $3=$ abundant macrophage and neutrophil).

The collected data were analyzed with Statistical Product and Service Solution (SPSS). The analysis was done to compare the score of GTF, ICC, RE and D from each MPE concentration group to unmedicated group. The statistical test used in this study was Mann-Whitney test with $\mathrm{P}<0.05$ considered as significant.

Table 1. Granulation tissue formation, reepithelization, inflammatory cell count, and wound bed diameter score for acute wound treated with mangosteen pericarp extract cream and untreated one after 3 and 8 days.

\begin{tabular}{|c|c|c|c|c|c|c|c|c|}
\hline & $\mathbf{N}$ & $\begin{array}{r}3 \text { days } \\
\text { Group (Concentration) }\end{array}$ & Mean & Std. Deviation & $\mathbf{N}$ & $\begin{array}{r}8 \text { days } \\
\text { Group (Concentration) }\end{array}$ & Mean & Std. Deviation \\
\hline GTF & $\begin{array}{l}4 \\
4 \\
4 \\
4\end{array}$ & $\begin{array}{c}\text { A (5\%) } \\
\text { B (10\%) } \\
\text { C (20\%) } \\
\text { E (unmedicated) }\end{array}$ & $\begin{array}{l}1.75 \\
1.25 \\
1.25 \\
1.25\end{array}$ & $\begin{array}{l}0.50 \\
0.50 \\
0.50 \\
0.50\end{array}$ & $\begin{array}{l}4 \\
4 \\
4 \\
4\end{array}$ & $\begin{array}{c}\mathrm{Al}(5 \%) \\
\mathrm{B} 1(10 \%) \\
\mathrm{Cl}(20 \%) \\
\text { E1 (unmedicated) }\end{array}$ & $\begin{array}{l}2.75 \\
2.75 \\
2.25 \\
1.75\end{array}$ & $\begin{array}{l}0.50 \\
0.50 \\
0.96 \\
0.50\end{array}$ \\
\hline RE & $\begin{array}{l}4 \\
4 \\
4 \\
4\end{array}$ & $\begin{array}{c}\text { A (5\%) } \\
\text { B (10\%) } \\
\text { C (20\%) } \\
\text { E (unmedicated) }\end{array}$ & $\begin{array}{l}2.25 \\
2.75 \\
2.25 \\
1.75\end{array}$ & $\begin{array}{l}0.50 \\
0.50 \\
0.50 \\
0.50\end{array}$ & $\begin{array}{l}4 \\
4 \\
4 \\
4\end{array}$ & $\begin{array}{c}\text { Al (5\%) } \\
\text { B1 (10\%) } \\
\text { Cl (20\%) } \\
\text { E1 (unmedicated) }\end{array}$ & $\begin{array}{l}3.75 \\
3.75 \\
3.50 \\
2.75\end{array}$ & $\begin{array}{l}0.50 \\
0.50 \\
0.58 \\
0.50\end{array}$ \\
\hline ICC & $\begin{array}{l}4 \\
4 \\
4 \\
4\end{array}$ & $\begin{array}{c}\text { A (5\%) } \\
\text { B (10\%) } \\
\text { C (20\%) } \\
\text { E (unmedicated) }\end{array}$ & $\begin{array}{l}2.50 \\
2.00 \\
2.00 \\
2.50\end{array}$ & $\begin{array}{l}0.58 \\
0.00 \\
0.00 \\
0.58\end{array}$ & $\begin{array}{l}4 \\
4 \\
4 \\
4\end{array}$ & $\begin{array}{c}\mathrm{Al}(5 \%) \\
\mathrm{B} 1(10 \%) \\
\mathrm{Cl}(20 \%) \\
\text { E1 (unmedicated) }\end{array}$ & $\begin{array}{l}1.25 \\
1.25 \\
2.00 \\
2.50\end{array}$ & $\begin{array}{l}0.50 \\
0.50 \\
0.82 \\
0.58\end{array}$ \\
\hline D & $\begin{array}{l}4 \\
4 \\
4 \\
4\end{array}$ & $\begin{array}{c}\text { A (5\%) } \\
\text { B (10\%) } \\
\text { C (20\%) } \\
\text { E (unmedicated) }\end{array}$ & $\begin{array}{l}3.98 \\
4.18 \\
4.45 \\
4.55\end{array}$ & $\begin{array}{l}0.13 \\
0.24 \\
0.10 \\
0.06\end{array}$ & $\begin{array}{l}4 \\
4 \\
4 \\
4\end{array}$ & $\begin{array}{c}\mathrm{Al}(5 \%) \\
\mathrm{B} 1(10 \%) \\
\mathrm{Cl}(20 \%) \\
\text { E1 (unmedicated) }\end{array}$ & $\begin{array}{l}2.00 \\
1.73 \\
2.75 \\
3.20\end{array}$ & $\begin{array}{l}0.24 \\
0.33 \\
0.53 \\
0.28\end{array}$ \\
\hline
\end{tabular}

GTF, granulation tissue formation; RE, reepithelization; ICC, inflammatory cells count; $\mathrm{D}$, diameter of wound bed. 


\section{Results}

The result of statistical analysis between the groups are shown in Tables 1-3. Table 1 describes mean score of GTF, ICC, RE and mean wound bed diameter of the 5\%, $10 \%$, and $20 \%$ MPE cream, and control group.

A preliminary study was done to measure the level of $\alpha$-mangostin in MPE; it was revealed that 1 gram MPE contained $2.8 \mathrm{mg}$ $\alpha$-mangostin (unpublished data).

\section{Three days after mangosteen pericarp extract cream application}

As described in Table 2, the wound diameter, RE, and GTF were all significantly higher in the MPE cream 5\% group compared to those in the control group $(\mathrm{P}<0.05)$. In the MPE cream $10 \%$ group, compared to the control group, a significantly higher RE (2.75 vs 1.75) and significantly lower wound bed diameter (D) (4.18 vs 4.56) were shown after three days $(\mathrm{P}<0.05)$. The results also suggest that ICC was lower compared to the control group. However, there was no significant difference between MPE cream $20 \%$ group and control group.

\section{Eight days after mangosteen pericarp extract cream application}

As described in Table 3, GTF and RE in the MPE 5\% group were significantly higher than the control group (mean 2.75 vs 1.75 and 3.75 vs 2.75, respectively) $(\mathrm{P}<0.05)$. In addition, ICC and $\mathrm{D}$ (mean=1.25, mean=2.00, respectively) were significantly lower than the control group (mean=1.25 vs 2.50 and 2.00 vs 3.20 , respectively) $(\mathrm{P}<0.05)$.

In addition, GTF and RE were also found to be significantly higher in MPE cream 10\% group than in the control group (mean 2.75 vs 1.75 and 3.75 vs 2.75 , respectively) $(\mathrm{P}<0.05)$. The ICC and $\mathrm{D}$ parameters were significantly lower (mean $=1.25$, mean $=1.73$, respectively) than the control group (mean=1.25 vs 2.50 and 1.73 $v s 3.20$, respectively) $(\mathrm{P}<0.05)$. However, there was no significant difference between MPE 20\% group and the control group.

\section{Discussion}

This study showed that topical application of MPE cream significantly influenced wound healing by increasing GTF and RE

Table 2. Comparison of granulation tissue formation, reepithelization, inflammatory cell count, and wound bed diameter score for acute wound treated with mangosteen pericarp extract cream and untreated one after 3 days.

\begin{tabular}{lcccc} 
& Group (Concentration) & Mean & Mean of Group E (Control) & P-value \\
GTF & A (5\%) & 1.75 & 1.25 & 0.17 \\
& B (10\%) & 1.25 & 1.00 \\
RE & C (20\%) & 1.25 & 1.75 & 1.00 \\
& A (5\%) & 2.25 & 0.17 & $\mathbf{0 . 0 4}$ \\
B (10\%) & 2.75 & 2.50 & 0.17 \\
ICC & C (20\%) & & 1.00 \\
& A (5\%) & 2.25 & 0.13 \\
D & B (10\%) & 2.50 & 0.13 \\
& C (20\%) & 2.00 & 4.55 & $\mathbf{0 . 0 2}$ \\
& A (5\%) & & $\mathbf{0 . 0 4}$ \\
\hline
\end{tabular}

GTF, granulation tissue formation; RE, reepithelization; ICC, inflammatory cells count; D, diameter of wound bed.

Table 3. Comparison of granulation tissue formation, reepithelization, inflammatory cell count, and wound bed diameter score for acute wound treated with mangosteen pericarp extract cream and untreated one after 8 days.

\begin{tabular}{|c|c|c|c|c|}
\hline & Group (Concentration) & Mean & Group E1 mean & P-value \\
\hline GTF & $\begin{array}{l}\text { Al }(5 \%) \\
\text { B1 }(10 \%) \\
\text { Cl }(20 \%)\end{array}$ & $\begin{array}{l}2.75 \\
2.75 \\
2.25\end{array}$ & 1.75 & $\begin{array}{c}\mathbf{0 . 0 4} \\
\mathbf{0 . 0 4} \\
0.36\end{array}$ \\
\hline $\mathrm{RE}$ & $\begin{array}{l}\mathrm{Al}(5 \%) \\
\mathrm{B} 1(10 \%) \\
\mathrm{Cl}(20 \%)\end{array}$ & $\begin{array}{l}3.75 \\
3.75 \\
3.50 \\
\end{array}$ & 2.75 & $\begin{array}{c}\mathbf{0 . 0 4} \\
\mathbf{0 . 0 4} \\
0.10\end{array}$ \\
\hline ICC & $\begin{array}{l}\mathrm{Al}(5 \%) \\
\mathrm{B} 1(10 \%) \\
\mathrm{Cl}(20 \%)\end{array}$ & $\begin{array}{l}1.25 \\
1.25 \\
2.00\end{array}$ & 2.50 & $\begin{array}{c}\mathbf{0 . 0 3} \\
\mathbf{0 . 0 3} \\
0.34\end{array}$ \\
\hline D & $\begin{array}{l}\mathrm{Al}(5 \%) \\
\mathrm{Bl}(10 \%) \\
\mathrm{Cl}(20 \%)\end{array}$ & $\begin{array}{l}2.00 \\
1.73 \\
2.75\end{array}$ & 3.20 & $\begin{array}{c}\mathbf{0 . 0 2} \\
\mathbf{0 . 0 2} \\
0.19\end{array}$ \\
\hline
\end{tabular}

GTF, granulation tissue formation; RE, reepithelization; ICC, inflammatory cells count; $D$, diameter of wound bed. 
and decreases the number of ICC. These effects were especially observed in $5 \%$ and $10 \%$ concentrations both 3 days and 8 days after application that were confirmed by histopathology examination. It was also shown that MPE 5\% and $10 \%$ cream application can accelerate wound bed closure.

Despite its long known anti-inflammatory activity, there is still lack of knowledge about the mechanism of action of xanthones. ${ }^{10,12}$ This effect mainly mediated by $\alpha$-mangostin, which is the most abundant xanthone in mangosteen pericarp. ${ }^{8}$

Inflammation begins with coagulation, platelet aggregation, and fibrin clot formation. ${ }^{1}$ These processes function to prevent cellular elements loss, to serve as physical barrier to prevent microorganism entry, and to act as provisional matrix, cytokine deposit and growth factors; all of which are fundamental for maintenance of subsequent healing phases. ${ }^{2}$ In the first few hours after injury, neutrophils are recruited and mediate tissue damage through the release of proteases, cytokines, and other factors contained in cytoplasmic granules. These cells generate reactive oxygen species (ROS) and produce antimicrobial proteases (cathepsins, defensins, lactoferrin, and lysozyme) with the function of destroying potentially pathogenic microorganisms. ${ }^{4}$ Neutrophils also produce various types of MMPs, involved in the extracellular matrix degradation. Uncontrolled neutrophil migration generates a cycle of recruitment activation of these cells leading to excessive ROS and proteases production, causing undesired ECM degradation and additional tissue damage, which may progress to chronic inflammation with consequent defective collagen deposition, reduced tissue resistance, and late reepithelialization which limits wound healing. ${ }^{4,13}$

It has been reported that $\alpha$-mangostin attenuates inflammation by blocking inducible nitric oxide synthase (iNOS) and cyclooxygenase-2 (COX-2) expression and by inhibiting prostaglandin E2 (PGE2). ${ }^{10}$ Gutierrez-Orozco et al. have investigated the inhibitory effect of $\alpha$-mangostin on secretion of proinflammatory mediators such as IL- 8 or TNF- $\alpha$ by human cell lines from various tissue origins, and found that $\alpha$-mangostin stimulated secretion of TNF- $\alpha$ in primary culture of human monocyte-derived macrophage cells. ${ }^{12}$ Another study has been done in silico, in vitro, and in vivo and conclude $\alpha$-mangostin acts via inhibition of NO, IL-1 $\beta$, and TNF- $\alpha$ and also established anti-inflammatory effect by NFkB inhibition and selective COX2 inhibition together with iNOS blockage. ${ }^{8}$

About four days after a wound onset granulation tissue begins to be made through increasing of fibroblastic proliferation, collagenous and elastic biosynthesis, which forms a threedimensional extracellular network of connective tissue. The granulation tissue fills the wound and provides covering condition for the newly formed epidermis. ${ }^{6}$ Two or three weeks after, the granulation tissue is gradually remodeled, forming a less cellular and vascular scar tissue. ${ }^{1}$

GTF and reepithelialization acceleration were confirmed in this study. However, it is still unclear how $\alpha$-mangostin induced GTF, especially fibroblast and epithelial migration. Faster wound healing might be due to the potential activity of $\alpha$-mangostin as anti-inflammatory, antioxidant, and anti-bacterial agent that accelerates healing process.

\section{Conclusions}

This study showed that MPE cream application can accelerate wound healing and thus can be used in acute wound for faster wound healing.

\section{References}

1. Gonzales ACO, Costa TF, Andrade ZA, Medrado ARAP. Wound healing - a literature review. An Bras Dermatol 2016;91:614-20

2. Serra MB, Barroso WA, da Silva NN, et al. From inflammation to current and alternative therapies involved in wound healing. Int J Inflam 2017;2017:3406215.

3. Tarameshloo M, Norouzian M, Zarein-Dolab S, et al. Aloe vera gel and thyroid hormone cream may improve wound healing in wistar rats. Anat Cell Biol 2012;45:170-7.

4. Landen NX, Li D, Stahle M. Transition from inflammation to proliferation: a critical step during wound healing. Cell Mol Life Sci 2016;73:3861-85.

5. Falanga V, Iwamoto S. Mechanisms of wound repair, wound healing, and wound dressing. In: Goldsmith LA, Katz SI, Gilchrest BA, et al., eds. Fitzpatrick's Dermatology in General Medicine. 2. New York, USA: McGraw-Hill; 2012. pp 2984-2996.

6. Charernsriwilaiwat N, Rojanarata T, Ngawhirunpat T, et al. Electrospun chitosan-based nanofiber mats loaded with Garcinia mangostana extracts. Int J Pharm 2013;452:333-43.

7. Gutierrez-Orozco F, Failla ML. Biological activities and bioavailability of mangosteen xanthones: a critical review of the current evidence. Nutriens 2013;5:3163-83.

8. Mohan S, Syam S, Abdelwahab SI, Thangavel N. Anti-inflammatory molecular mechanism of action of $\alpha$-mangostin, the major xanthones from the pericarp of Garcinia mangostana; an in silico, in vitro and in vivo approach. Food Funct 2018;9:3860-71.

9. Tatiya-Aphiradee N, Chatuphonprasert W, Jarukamjorn K. In vivo antibacterial activity of Garcinia mangostana pericarp extract against methicillin-resistant Staphylococcus aureus in a mouse model superficial skin infection model. Pharm Biol 2016;54:2606-15.

10. Chen LG, Yang LL, Wang CC. Anti-inflammatory activity of mangostins from Garcinia mangostana. Food Chem Toxicol 2008;46:688-93.

11. Sugihartini N, Wiradhika RY. Gel formulation of ethanol extract of mangosteen peel (Garcinoa mangostana L.) as a medication for burns in wistar rats. JKKI 2017;8:110-7.

12. Gutierrez-Orozco F, Chitchumroonchokchai C, Lesinski G, et al. $\alpha$-mangostin: anti-inflammatory activity and metabolism by human cells. J Agric Food Chem 2013;61:3891-900.

13. Oliveira S, Rosowski EE, Huttenlocher A. Neutrophil migration in infection and wound repair: going forward in reverse. Nat Rev Immunol 2016;16:378-91. 